\title{
STUDI LIFE HISTORY IDENTITAS DAN INTERAKSI SOSIAL PADA KETURUNAN TIONGHOA MUSLIM
}

\author{
Ria Mei Andi Pratiwi dan Muhammad Syafiq \\ Program Studi Psikologi Universitas Negeri Surabaya
}

\begin{abstract}
This study aims to explore how Chinese Muslims sense their identity, since they are individual with multiple identities, and how their identity influences their social interaction. This study used a qualitative approach with a life history method. Two male Chinese Muslims were recruited to involved in this study. Data collected using semi structured interviews and analyzed using thematic analysis. This study founds two main themes namely identity struggle and social interaction. Both of participants have a different way of social struggle because of different family and surrounding people. The results of this study shows that both of them have a strategy to maintain their positive self identity through identity negotiations. They choose one of their social identities based on the surrounding people they live in. In general, this study concluded that both participants are able to adapt to different kind of social interaction by selecting and emphasizing social identity appropriate to the context. Thus, they show the ability to deal with multiple identities in healthy ways.
\end{abstract}

Keywords: Chinese Muslim, Identity, Social Interactions.

\begin{abstract}
Abstrak: Penelitian ini bertujuan untuk mengetahui bagaimana keturunan Tionghoa yang memeluk agama Islam ini memaknai identitasnya sebagai individu dengan identitas majemuk, serta bagaimana identitasnya tersebut mempengaruhi interaksi sosialnya. Penelitian ini menggunakan pendekatan kualitatif life history dengan partisipan penelitian berjumlah dua orang yang diperoleh dengan teknik purposive sampling. Proses pengambilan data menggunakan teknik wawancara semi terstruktur. Data penelitian ini kemudian dianalisis menggunakan teknik analisis tematik. Hasil dari penelitian ini menunjukkan dan mengidentifikasi dua tema utama, yakni tentang pergulatan identitas, dan interaksi sosial. Kedua partisipan mempunyai pergulatan identitas dengan cara yang berbeda dikarenakan kondisi keluarga dan lingkungan sekitar. Hasil dari penelitian ini juga menunjukkan bahwa kedua partisipan memiliki strategi untuk menjaga identitas diri yang positif melalui negosiasi identitas. Mereka memilih salah satu dari identitas sosial mereka sesuai dengan lingkungan sekitar mereka. Secara umum, kesimpulan dari penelitian ini adalah kedua pertisipan mampu untuk mengadaptasi berbagai jenis interaksi sosial dengan memilih dan menegaskan identitas sosial mereka sesuai dengan konteks. Disamping itu, mereka juga menunjukkan kemampuan mereka untuk memaknai identitas ganda dengan baik.
\end{abstract}

Kata Kunci: Tionghoa Muslim, Identitas, Interaksi Sosial

Indonesia merupakan negara multikultural dengan penduduk yang berasal dari berbagai latar belakang etnis, suku, agama, ras dan budaya. Keberagaman ini mengakibatkan banyaknya interaksi dengan segala macam dinamika sosialnya. Pada umumnya, kelompok etnis tertentu tinggal di pemukiman yang terdiri atas etnis yang sama. Mereka cenderung membentuk kelompok yang ekslusif baik dalam pendidikan, sekolah maupun tempat ibadah. Interaksi sosial antara etnis Tionghoa dengan masyarakat dari etnis lainnya khususnya Jawa tak lepas dari bayang-bayang sejarah yang mempengaruhi hubungan kedua etnis ini. Pada zaman kolonial, Belanda menuduh Tionghoa memeluk Islam untuk menghindari pajak dan memperoleh akses berdagang yang lebih luas, padahal pada tahun 1400 an disebutkan dalam kitab karangan haji Ma Huan (吗换) bahwa

Korespondensi tentang artikel ini dapat dialamatkan kepada Ria Mei Andi Pratiwi melalui e-mail: yesunghae@ymail.com 
telah ada pembauran antara hui ( biasa disebut 会人) dan pribumi, muslim Tionghoa, dan Tionghoa non-muslim (Perkasa, 2012). Integrasi Tionghoa muslim dan non muslim dengan masyarakat pribumi menjadi faktor penting perkembangan kota-kota di Jawa dan tumbuhnya pusat-pusat aktivitas pada saat itu. Bahkan sepanjang abad ke 16 dan 17, populasi muslim Tionghoa terus meningkat dan memainkan peran penting dalam perdagangan (Setiawan, 2012).

Salah satu kisah akulturasi Tionghoa dengan Jawa sempat ditulis dalam bentuk novel oleh Tjoa Boe Sing dan dimuat sebagai cerita bersambung di surat kabar Jawa Tengah, Semarang pada tahun 1910. Kemesraan ini berlangsung terus sampai akhir abad ke 17 dan memasuki abad ke 18, "kemesraan" Tionghoa Jawa mengalami penurunan. Hal ini dkarenakan beberapa sebab yaitu adanya ketegangan yang muncul di dalam komunitas Tionghoa itu sendiri yang dipicu menurunnya jumlah muslim Tionghoa dikarenakan berbagai sebab, antara lain perubahan politik di daratan Cina, berakhirnya dinasti Ming, Manchu menguasai Cina dan menerapkan kebijakan-kebijakan yang menyulitkan warga muslim, ditambah kebijakan Belanda yang mengarahkan Islam menjadi lebih ortodoks yang juga menjadi penyebab utama menurunnya jumlah Tionghoa muslim. (Setiawan, 2012).

Faktor selanjutnya yaitu pembantaian etnis Tionghoa pada tahun 1740 semakin memperburuk hubungan Tionghoa dengan etnis Jawa, dan jumlah muslim Tionghoa pun mengalami penurunan drastis menjadi sekitar 4.800 orang dari sekitar 11.000 orang, karena banyak yang memutuskan pindah ke tempat yang lebih aman dan membentuk perkumpulan yang cenderung ekslusif (Setiawan, 2012).

Faktor lain yang mempengaruhi hubungan antara Tionghoa dengan Pribumi adalah bahwa warga Tionghoa yang melakukan pembauran dengan warga setempat juga sering dikategorikan sebagai kelompok dengan tingkat ekonomi yang rendah, atau kurang beruntung dalam ekonomi. Mereka dianggap berbaur untuk mendapatkan jaminan sosial (social security) dari warga setempat. Sebab warga Tionghoa yang kurang mampu ini dianggap kurang pantas berbaur dengan Tionghoa yang sukses secara ekonomi karena diantara mereka juga terjadi kesenjangan secara ekonomi. Hal ini juga secara langsung berdampak pada interaksi mereka, terlebih untuk Tionghoa yang beragama Islam, sebab mereka mendapat double stereotip baik oleh sesama kaum Tionghoa maupun oleh warga pribumi. Tentunya hal ini menimbulkan hambatan tersendiri dalam interaksi mereka di masyarakat (Setiono, 2005).

Menilik sejarah panjang yang dialami oleh leluhur mereka, warga Tionghoa muslim ini pun berinisiatif mendirikan perkumpulan bagi sesama kaum Tionghoa yang beragama Islam, yang bertujuan membantu dan menyatukan sesama Tionghoa muslim. Komunitas muslim Tionghoa ini tergabung dalam wadah sebuah organisasi yang bernama Pembina Iman Tauhid Islam (PITI). Dulu PITI adalah singkatan dari Persatuan Islam Tionghoa Indonesia. Pergantian nama dari Persatuan Islam Tionghoa Indonesia menjadi Pembina Iman Tauhid Islam terjadi pada masa orde baru karena adanya larangan penggunaan aksara Cina yang masih terdapat dalam nama perkumpulan tersebut (Maulana, 2010)

Kelompok maupun perkumpulan warga Tionghoa muslim ini kurang mendapat perhatian dari masyarakat, maka dengan adanya PITI ini membuktikan bahwa anggapan negatif tentang etnis Tionghoa ini kian tak terbukti dan mereka pun juga membuktikan diri sebagai bagian dari masyarakat yang bisa mengorganisasi diri guna menciptakan iklim kehidupan sosial yang beragam namun tetap bersatu ( Maulana, 2010).

Sejauh ini PITI berdiri hampir di seluruh wilayah di Indonesia. Bila didata secara akurat jumlah muslim Tionghoa di Indonesia cukup besar jumlahnya. Di Jawa Timur khususnya di Surabaya, jumlah muslim Tionghoa semakin banyak mengalami perkembangan dan penyebarannya juga kian pesat, ini mengingat kota Surabaya 
merupakan kota tertua dan terbesar di pulau Jawa (Siburian, 2004).

PITI yang juga membangun tempat ibadah bagi muslim Tionghoa maupun umum yang diberi nama masjid Cheng Hoo. Masjid ini digunakan sebagai sarana pengembangan dan lembaga dakwah islam khususnya terhadap warga Tionghoa. Berbagai kegiatan dakwah maupun kegiatan keagamaan dilakukan di masjid ini guna memberikan pemahaman yang lebih mendalam tentang agama Islam terhadap warga Tionghoa. Masjid ini dibuka juga untuk masyarakat umum, oleh karena itu banyak interaksi sosial yang terjadi antara warga Tionghoa dengan masyarakat sekitar yang menggunakan fasilitas masjid ini. Hal ini diharapkan menambah rasa persaudaraan sesama muslim dikarenakan walaupun berbeda namun masih dalam satu tanah air yaitu Indonesia (Setiono, 2005 )

Berkaca dari sejarah ini dan melihat fenomena yang terjadi saat ini, peneliti ingin mengungkap bagaimana Tionghoa khususnya yang muslim berinteraksi di luar perkumpulan sesama Tionghoa muslim, baik dengan Tionghoa non muslim maupun etnis yang lainnya. Karena menilik sejarah mereka pada zaman kolonialisme sampai era reformasi sekarang ini yang menjalani suatu proses panjang untuk mendapatkan pengakuan dan kebebasan dalam menjalankan hak-haknya dalam masyarakat dan tentunya etnis Tionghoa ini mengalami banyak usaha penyesuaian diri dalam masyarakat, terutama dalam interaksi di kehidupan sehari-hari (Setiawan, 2012).

Riset tentang etnis Tionghoa telah banyak dilakukan, baik dalam bentuk jurnal, skripsi maupun buku. Adapun riset yang mengkaji khusus tentang etnis Tionghoa muslim juga mulai banyak dilakukan, karena hal ini merupakan tema yang berkaitan dengan ranah ilmu sosiologi, antropologi, kajian agama Islam maupun psikologi. Maulana (2010) melakukan penelitian tentang pergulatan Identitas Muslim Tionghoa di Yogyakarta. Penelitian tersebut menjelaskan tentang dinamika sosial anggota etnis Tionghoa sebagai muslim, proses dakwah kultural, serta keikutsertaan Tionghoa muslim ini dalam acara-acara keagamaan di Yogyakarta dan partisipasi mereka dalam pembangunan dan pendidikan agama Islam khususnya di daerah tersebut. Penelitian tersebut menunjukkan bahwa kaum Tionghoa di Yogyakarta yang beragama Islam memiliki identitas yang berlapis dan cenderung kesulitan untuk menentukan standar identitas yang akan digunakan. Mereka juga akan mengidentifikasikan identitas ke Tionghoaan mereka sesuai dengan situasi yang ada dan perubahan yang terjadi di sekitar mereka.

Penelitian lain dilakukan oleh Afif (2009) tentang strategi anggota etnis Tionghoa Muslim di Yogyakarta dalam mencapai identitas sosial yang positif. Penelitian ini mengungkap bagaimana pencapaian identitas positif mempengaruhi interaksi anggota etnis Tionghoa muslim dengan etnis lainnya di Yogyakarta. Penelitian tersebut menyimpulkan bahwa ada perbedaan motif dan strategi untuk mencapai identitas sosial yang positif di kalangan anggota etnis Tionghoa muslim sendiri. Pada Tionghoa totok, mereka masuk Islam untuk kepentingan personal dan lebih memilih strategi mobilitas individual dan strategi optimalisasi keunikan untuk mencapai identitas positif, sedangkan pada Tionghoa peranakan mereka masuk Islam karena faktor lingkungan sehingga strategi yang dipilih adalah strategi kreativitas sosial.

Penelitian selanjutnya dilakukan oleh Jendra (2012) tentang konsep diri muallaf etnis Tionghoa berfokus pada bagaimana peran significant others mempengaruhi konsep diri maupun kepercayaan diri dari muallaf Tionghoa. Kesimpulan dari penelitian ini juga menunjukkan bahwa significant others memiliki peran yang penting dalam pengambilan keputusan maupun sebagai tolak ukur rasa percaya diri dari seorang muallaf Tionghoa.

Beberapa penelitian di atas menunjukkan bahwa anggota etnis Tionghoa Muslim berada dalam posisi yang melampaui batas satu identitas tunggal tertentu yang kaku. Menjadi Tionghoa sekaligus beragama Islam memunculkan pengalaman yang 
kompleks yang berimplikasi pada pembentukan identitas diri dan interaksi sosial mereka baik dengan sesama etnis Tionghoa bukan muslim maupun dengan sesama muslim dari etnis mayoritas khususnya Jawa. Hal ini tentu saja sangat menarik dan penting untuk diteliti karena sebagaian masyarakat masih memiliki stereotip tertentu terhadap etnis Tionghoa (Susetyo, 2010). Suatu stereotip muncul karena adanya ketidaktahuan ataupun kesalahan persepsi pada masingmasing pihak (Baron \& Byrne, 2004). Penstereotipan (stereotyping) terhadap etnis Tionghoa ini menyebabkan pandangan yang menggeneralisasir kelompok ernis Tionghoa tersebut sebagai suatu blok yang monolit di mata pribumi. Padahal dalam masyarakat Tionghoa itu sendiri juga terdapat pluralisme yang tidak kalah kompleksnya (Susetyo, 2010).

Penelitian ini bertujuan untuk mengungkap bagaimana identitas diri dan interaksi sosial anggota etnis Tionghoa muslim dalam konteks kehidupannya dalam keluarga sesama etnis Tionghoa bukan muslim dan komunitas Muslim di sekitar mereka.

\section{METODE}

Penelitian ini menggunakan pendekatan kualitatif dengan metode life history. Penelitian life history dipandang paling tepat digunakan karena data yang diungkap berupa pengalaman kisah hidup yang berbentuk narasi (Bungin, 2010). Penelitian ini menggunakan riwayat kehidupan personal setiap subjek hingga saat ini sebagai data utama untuk dianalisis.

\section{Partisipan}

Pengambilan partisipan pada penelitian ini menggunakan teknik purposive sampling. Life history yang lebih mengacu pada pengalaman hidup mendasari peneliti menetapkan dua orang sebagai partisipan. Partisipan pertama yaitu Andre (bukan nama sebenarnya) adalah keturunan Tionghoa muslim yang merupakan campuran Jawa dan
Tionghoa. Berusia 20 tahun dan sedang menempuh pendidikan di salah satu perguruan tinggi swasta di Surabaya. Partisipan kedua yaitu Alex (bukan nama sebenarnya), berusia 20 tahun, keturunan Tionghoa Jawa, muslim sejak lahir dan merupakan mahasiswa semester 4 di salah satu perguruan tinggi swasta di Surabaya.

\section{Teknik Pengumpulan Data}

Teknik pengumpulan data yang digunakan dalam penelitian ini adalah wawancara semi-terstruktur dengan menggunakan pedoman wawancara yang tidak diikuti secara ketat. Pedoman wawancara berisi dua pokok bahasan yakni mencakup identitas sosial partisipan sebagai keturunan Tionghoa yang muslim, serta bagaimana interaksi sosial mereka di masyarakat. Subjek diminta menceritakan pengalaman hidupnya mulai dari masa anakanak dan remajanya, bagaimana interaksinya dalam keluarga maupun lingkungan sekitar, bagaimana interaksinya dengan sesama Tionghoa muslim maupun Tionghoa non muslim, dan juga dengan pribumi, apa saja hambatannya menjadi seorang muslim dan seberapa besar pengaruh identitasnya sebagai Tionghoa muslim terhadap interaksinya sehari-hari.Alat pengumpul data yang digunakan adalah buku catatan dan alat perekam.

Proses pengambilan data dilakukan selama tiga bulan dengan didahului pembangun rapport selama kurun waktu satu hingga dua minggu. Proses wawancara dilakukan dalam dua kali pertemuan, yang berkisar antara 45 menit hingga 120 menit tanpa kehadiran pihak ketiga.

\section{Teknik Analisis Data}

Penelitian ini menggunakan analisis data tematik seperti yang disarankan oleh Braun dan Clarke (2006). Teknik ini diawali dengan mentranskrip data hasil wawancara berupa verbatim, dilanjutkan dengan melakukan coding, yaitu memberi komentar atau tafsiran atas data asli dengan menuliskan kata, frase, atau kalimat singkat di marjin 
kanan. Hasil coding kemudian dikategori menjadi beberapa kelompok topik dan dilabeli nama sub-tema. Seluruh sub-tema yang teridentifikasi selanjutnya dikategori lagi dalam beberapa kelompok tema utama. Analisis data dilakukan kasus per kasus.

\section{HASIL}

Penelitian ini berhasil mengindentifikasi dua tema utama yaitu pergulatan identitas dan interkasi sosial antara dua partisipan yaitu Alex dan Andre.

\section{Tema: Pergulatan identitas (Alex)}

Alex (nama samaran) merupakan seorang remaja berusia 20 tahun yang merupakan keturunan campuran antara Tionghoa dengan Jawa yang memeluk agama Islam. Alex merupakan anak kedua dari dua bersaudara, kebetulan kakaknya sudah berkeluarga dan memiliki seorang putri. Secara umum hidup Alex sudah sangat berkecukupan dan tidak ada masalah berarti dalam keluarganya, dalam artian dia hidup dengan ayah, ibu dan seorang kakak yang sudah berkeluarga dan mereka hidup harmonis. Hanya saja statusnya sebagai keturunan Tionghoa terkadang membuatnya merasa berbeda, hal ini diungkapkannya sebagai berikut:

\section{"awalnya saya juga nggak seberapa apa ya mikirin, tapi lama kelamaan ya banyak yang bilang, kalo saya ini oh dasar anaknya Cina apalagi kalo saya sedang pulang ke desa."}

Alex sendiri mengakui dirinya mulai menyadari bahwa dia berbeda dengan anak lainnya, namun dia lebih mengidentifikasikan dirinya sebagai orang Jawa, dia juga tidak memungkiri bahwa dirinya merupakan keturunan Tionghoa, hal ini dikarenakan kondisi fisiknya yang lebih cenderung menonjol Jawa-nya,

"kalo saya sendiri sih menganggap diri saya lebih ke Jawa nya ya, soalnya saya juga nggak seputih orang Cina, dan tidak terlalu kelihatan dari mana Cina nya..jadi ya anggap saja saya ini orang biasa cuma orang-orang pasti melihat dari mata saya yang seperti pada umumnya orang Cina."

Kondisinya sebagai seorang keturunan Tionghoa muslim pun menjadi satu hal yang membuatnya merasa sekali lagi berbeda dengan teman-teman lainnya. Mayoritas keturunan Tionghoa memeluk agama non muslim, misalnya Budha maupun Konghuchu ataupun Kristen, sedangkan dirinya memeluk Islam sejak lahir, hal ini tentu saja membuatnya merasa semakin merasa ada yang berbeda dengan dirinya.

"eh..saya melihat diri saya itu ya semakin lama saya menyadari bahwa saya itu eh agak sedikit berbeda dari anak-anak ya, anak-anak itu istilahnya apa ya, banyak yang keturunan Jawa temen-temen saya itu, dan mereka juga muslim bahkan ada yang non muslim, tapi mereka itu Jawa, tapi sedangkan saya diperkirakan oleh orang-orang yang lain malahan saya itu seorang Islam. Jadi ada yang percaya ada yang ndak percaya juga, kalo saya lihat itu ya beginilah saya sejak lahir sudah sebagai seorang muslim hingga sampai saat ini."

Penyatuan kultur yang berbeda dari pernikahan orang tuanya sempat membuat Alex merasa bingung dengan identitas agamanya, dikarenakan lingkungan sekitar yang berbeda dan dirinya juga masih kurang paham tentang konsep agama yang dianutnya.

"eh..ini dulu saya pernah mengalami kejadian lucu ya sebenernya, jadi keluarga saya itu ada yang pergi ke gereja..dan sedangkan saya kan masih kecil, saya ikut aja gitu ke gereja juga dan saya gak tau harus apa, biasanya orang tua saya itu berdoa begini tapi ini kok malah begini, saya jadi bingung mau gimana, apa saya ini mau ikut sini atau ikut sana gitu...ya itu namanya masih kecil ya tapi sekarang udah besar ya saya sudah tahu kalo waktu saya hanya seorang anak kecil 
yang gak tahu apa-apa, jadi masih bingung."

Dibesarkan dalam perbedaan membuat Alex tumbuh menjadi seorang individu yang menghargai perbedaan di sekitarnya, dan menanggapi banyaknya keturunan Tionghoa yang non muslim, dirinya mengatakan menghargai dan menghormati keputusan tiap individu untuk memeluk agama.

\begin{abstract}
"kalau menurut saya sih memeluk agama itu hak masing-masing orang, jadi walaupun meraka mau memilih agama non muslim ataupun muslim terserah, tapi pastinya banyak sekali ya orang Tionghoa itu memilih non muslim, entah kenapa saya juga kurang tau tapi mugkin pada keturunan yang dulu mereka sudah memegang ajaran non muslim juga jadi mungkin sampai saat ini masih terbawa gitu,"
\end{abstract}

Sedangkan menanggapi stereotip di masyarakat tentang keturunan Tionghoa, serta pengaruh identitasnya sebagai keturunan Tionghoa dalam interaksinya sehari-hari Alex mengungkapkan pendapatnya sebagai berikut,

"saya sih fine-fine (baik-baik) aja ya..ya saya juga kayak anak-anak yang lain gitu lho jadi walaupun mereka berbeda agama atau berbeda apa ya keturunan, saya sih nggak merasakan itu, yang penting saya nyaman berbicara sama mereka ya kita enjoy (nyaman) aja gitu mbak, kita jalani aja tanpa harus memperrdebatkan agamaagama kita atau hal yang lain gitu."

\section{Pergulatan identitas (Andre)}

Andre merupakan remaja berusia 20 tahun, anak pertama dari tiga bersaudara. Andre juga merupakan keturunan Tionghoa yang memeluk agama Islam. Darah Tionghoa diturunkan dari ibunya yang merupakan seorang perempuan Tionghoa asal Jogjakarta, sedangkan ayahnya merupakan seorang Jawa. Statusnya sebagai seorang keturunan Tionghoa yang memiliki ciri fisik layaknya orang Tionghoa membuatnya merasa berbeda dan memiliki pengalaman yang kurang berkenan di masa kecilnya.

\section{"dikucilkan itu jadi ya dibeda-bedakan, ya orang Cina itu seperti dihindari seperti diejek-ejek atau gimana gitu."}

Perlakuan ini diterimanya sampai dirinya menginjak masa remaja dan mulai memasuki SMA. Andre bersekolah di sekolah yang siswanya multi etnis, dan masalah perbedaan etnis menjadi hal yang biasa dan tidak menjadi masalah lagi baginya,

"Semenjak SMA itu baru ya biasa-biasa aja kayak nggak ada perbedaan antara orang Cina dan orang Jawa."

Identitas agamanya sebagai seorang muslim juga mendapatkan reaksi yang berbeda dari masyarakat terkait stereotip bahwa keturunan Tionghoa itu pasti non muslim,
"ya saya ini cuma banyak yang mengira kalau saya ini bukan muslim, nah waktu saya pakai baju koko gitu dikiranya loh kamu kok Islam, tak kirain Kristen gitu aja"

Masalah identitas agamanya sebagai seorang muslim tidak hanya itu, bahkan secara pribadi Andre mengungkapkan bahwa semasa kanak-kanak dirinya sempat merasa bingung dan tidak tahu apapun tentang agama Islam, serta tata cara ibadah maupun peraturan-peraturan dalam agama Islam itu sendiri, hal ini terkait status ibunya yang masih muallaf, sehingga belum lama memeluk agama Islam dan kurang seberapa mengerti tentang Islam. Sedangkan ayahnya yang memang seorang muslim, kurang mengajarkan juga tentang agama Islam pada dirinya,

"iya dulu itu masih belajar-belajar karena dulu itu gimana ya orang tua saya kurang mengajarkan tentang itu, karna orang tua saya itu sebenernya yang perempuan itu muallaf, dan yang laki-laki juga dulunya nggak begitu paham tentang shalat, 
jadinya ya belum diajarkan jadinya ya saya ngaji sendiri, ya dari itu baru saya tentang shalat, mengaji dan puasa"

Berbeda dengan Alex, status ibunya sebagai seorang Tionghoa dan menjadi muallaf menjadikan dirinya merasa berbeda dengan keluarganya, khususnya keluarga dari pihak ibunya, namun saat hal ini sudah berbeda

"banyak saudara saya itu yang dulunya banyak kan dari orang tua saya yang perempuan itu beragama Katolik, nah setelah mereka itu mendapat suami, suami mereka itu kebanyakan Islam jadinya akhirnya memeluk agama Islam semua, hampir semuanya, cuman ada dua keluarga yang masih menganut agama Katolik."

Terkait identitasnya sebagai keturunan Jawa dan Tionghoa, walaupun Andre yang memiliki ciri fisik seperti Tionghoa lebih suka dianggap sebagai orang Jawa,

"saya lebih suka disebut sebagai orang Jawa daripada orang Cina, mungkin karna dulu perbedaan Cina itu sangat besar ya, sering ada kericuhan karena perbedaan ras itu, karena ilok-ilokkan (ejek-ejekkan), karena perkataan yang kurang enak mungkin kepada orang Cina, jadi saya lebih sampai sekarang pun masih keinget eh..saya lebih suka disebut orang Jawa daripada orang Cina."

Menanggapi stereotip yang selama ini melekat di masyarakat terhadap keturunan Tionghoa, berikut penuturannya

"ya sering dibilang begitu cuman saya bilang kalo nggak semuanya orang Cina itu begitu, orang tua saya sendiri juga ada darah orang-orang Jawa asli ya jadi kalo dibilang kayak orang Cina kebanyakan ya nggak juga karena kebanyakan Cina kan emang mayoritas pengusaha kalo orang Jawa itu biasa-biasa aja, ya kebanyakan biasa-biasa aja, jadi saya ya nggak seberapa suka lah kalo dibilang kaya atau dibeda-bedakan terlalu tinggi lah, saya malah nggak suka."
Andre mengungkapkan bahwa dirinya tidak ingin identitasnya sebagai keturunan Tionghoa mempengaruhi interaksinya seharihari, berikut penuturannya,

"biasa-biasa aja lebih nyaman ya dianggap seperti orang-orang biasa nggak terlalu derajatnya lebih tinggi ya nggak, biasa aja lah disamakan sama yang lain, lebih suka disamakan"

\section{Tema : Interaksi sosial (Alex)}

Interaksi merupakan hal yang penting dalam kehidupan. Interaksi yang dimaksud ini bisa interaksi dengan keluarga, lingkungan tempat tinggal, maupun teman-teman sepermainan dan lingkungan tempat belajar (sekolah atau kampus). Alex mengakui bahwa sebagai mahasiswa, kebanyakan waktunya dihabiskan di kampus dan mengakibatkan interaksi dengan teman-teman di lingkungan kampusnya menjadi lebih intens.

\section{Interaksi dengan teman sebaya}

Menempuh pendidikan di universitas yang mayoritas mahasiswanya adalah etnis Jawa, membuat Alex merasa lebih nyaman dan lebih banyak memiliki teman yang berasal dari etnis Jawa daripada Tionghoa,

\section{"mungkin kalo kita sama Tionghoa muslim kan sesama pemuda ya jadi masih enak lah ngomongnya gitu, kalo sama yang dewasa-dewasa mungkin kurang ada ya, dari dosen atau apa gitu jarang ya, sedangkan kalo yang di lingkungan sekitar itu ya kalo pendapat saya sih orang Tionghoa itu jarang, jarang misalnya apa ya, mengobrol sama tetangga atau bergaul itu kan jarang kelihatan jadi kita itu eh..kalo dibilang ya jadi mungkin agak susah meskipun walaupun agama kita itu sama, muslim ataupun non muslim gitu"}

Alex pun mengungkapkan bahwa dirinya juga mempunyai teman sesama Tionghoa, namun hubungannya tidak sedekat dengan teman-temannya dari etnis Jawa. 
"kalo (kalau) dibilang baik ya pastinya baik mbak, tetapi tidak begitu apa ya akrab gitu lah, istilahnya wes (sudah) biasa biasa aja."

\section{Hubungan dengan keluarga}

Alex mengungkapkan bahwa hubungan dengan keluarga dari pihak ayahnya ini mengalami sedikit hambatan atau dia menyebutnya sebagai sebuah problem.

"kalo hubungan dengan keluarga dari pihak ayah sih, eh..ya jujur saja agak sedikit apa ya ada sedikit masalah problem (masalah) gitu ya, soalnya kan yang eh.. muslim itu dari keluarga ayah saya itu hanya ayah saya sendiri dan yang lain kan memiliki 6 saudara dan semua itu non muslim semua, jadi kalo ketemu ya ngobrol kalo nggak ya jarang ketemu, nggak pernah dalam seminggu itu kita bertemu berapa kali, mungkin satu bulan itu aja belum tentu ketemu, jarang."

Alex juga mengakui bahwa hubungannya dengan keluarga dari pihak ayahnya tidak sedekat dirinya dengan keluarga dari pihak ibu.

"kalau saya lihat sih sebetulnya hubungannya kurang begitu baik sih, jarang ketemu sama keluarga, kalau dari pihak ayah sana, jadi kayak (seperti) udah mengurusi keluarganya masing-masing gitu."

Alex juga mengungkapkan bahwa dirinya lebih nyaman berkumpul dengan keluarga dari pihak ibu yang merupakan Jawa dan muslim daripada keluarga dari pihak ayahnya.

\section{Interaksi dengan lingkungan tempat tinggal}

Dalam pergaulannya sehari-hari dengan orang yang mayoritas muslim, Alex mengakui bahwa dirinya menjalani kehidupannya apa adanya, tanpa terlalu menjadikan identitasnya sebagai beban, bahkan dia menyebut dirinya sebagai orang yang "easy going", dan dia tidak pernah merasa identitasnya sebagai keturunan
Tionghoa maupun sebagai muslim menjadi hambatan berarti baginya,

"kalau hambatan sih saya rasa nggak ada mbak, soalnya ya kita tahu sendiri agama itu sudah pilihan setiap orang, jadi walaupun apa agamanya saya nggak ada hambatan sama sekali, jadi saya itu walaupun berkumpul dengan kaum orangorang Tionghoa maupun orang-orang yang kalangan atas, itu nggak ada masalah sama sekali."

Namun Alex pun juga mengakui bahwa intensitas pertemuannya dengan orangorang di lingkungannya cenderung kurang sehingga dirinya pun juga jarang berinteraksi dengan mereka.

"eh..ya sedikit susah sih apalagi saya di perumahan ya rumah saya kan di perumahan, jadi lebih susah menemui orang-orang yang ada keturunan dari Tionghoa apalagi mereka itu jarang keluar-keluar rumah gitu, ya pastinya ada cuma jarang-jarang aja ketemu gitu."

Terkait identitasnya sebagai keturunan Tionghoa muslim, Alex mengungkapkan bahwa tidak ada hambatan berarti dalam interaksinya dikarenakan identitasnya,

"kalau saya sendiri saya juga mengalami cuma kalo masalah hambatan saya nggak menemukan soalnya gimana ya, saya itu orangnya enjoy (nyaman) saja sama siapapun orangnya walaupun dari mana saya itu enak-enak aja gitu mbak, saya nggak mempedulikan apa maksudnya dia itu dari kalangan mana, walaupun teman saya juga gitu nggak mempedulikan masalah siapa saya, darimana saya nggak sampai gitu."

Secara umum, Alex mengungkapkan mengenai pemaknaan dirinya terkait dirinya yang merupakan seorang individu dengan identitas majemuk,

"ya kalau saya memaknai diri saya sendiri itu eh..ya wes (sudah) begini ini saya dan apapun agama saya apapun keturunan saya, saya masih diterima di kalangan orang-orang Jawa, jadi saya ya bersyukur temen-temen saya maupun orang di 
sekeliling saya bisa menerima apa adanya saya, jadi kita itu nggak sampe (sampai) kepikiran orang ini gini nggak pernah, biasa gitu."

\section{Tema : Interaksi sosial (Andre)}

Sedangkan Andre (nama samaran), tentunya mengalami perbedaan dengan Alex dalam hal interaksinya sehari-hari. Bagi Andre interaksi merupakan wadah baginya untuk mengungkapkan pendapat, ide-ide serta berbagi wawasan dan pembelajaran hidup dengan sesamanya.

\section{Interaksi dengan teman sebaya}

Andre yang merupakan mahasiswa di salah satu perguruan tinggi swasta di Surabaya mengungkapkan bahwa di kampusnya tidak ada lagi perbedaan atau pun pembedaan berdasarkan ras atau agama.

\section{"kalau di kampus nggak ada perbedaan ya antara yang Tionghoa sama yang non Tionghoa, tetap perlakuannya sama aja tetep pergaulannya juga sama satu kampus itu nggak ada perbedaan"}

Andre mengungkapkan bahwa dirinya mempunyai teman dekat di kampus yang sesama keturunan Tionghoa, dan dia nyaman berteman dengan temannya tersebut.

"ada, ya saya kalau sama dia juga biasa aja ya mungkin sahabatan gitu lah, tapi nggak terlalu deket-deket juga sih,"

Andre merasa dirinya nyaman berteman dengan sesama keturunan Tionghoa dikarenakan adanya persamaan budaya.

"ya sering ada masalah cuman bisa diatasi lah dengan omongan-omongan biasa ya nggak seperti kalo sama yang lainnya, kalo sama orang Jawa misalnya masih ada gondok-gondoknya (tersinggungnya) tapi kalo sama ini ya sama lah wong adatnya sama juga"

Andre juga mengungkapkan bahwa di kampus dirinya mempunyai semacam kumpulan yang terdiri dari etnis Jawa dan Tionghoa.

"ya saya di kampus itu punya seperti satu kumpulan ya, nah itu ada Jawa ada Cina juga, nah kalo yang ke non Cina itu ya biasa aja cuma eh..perbedaan pendapat itu sering ada ya"

Namun Andre juga mengungkapkan bahwa dalam berteman dirinya tidak suka memilih-milih yang penting baginya adalah teman tersebut dapat menghargainya.

"sama aja sih, yang penting anaknya baik aja terus bisa eh..bisa pegang omongan nggak sembrono (sembarangan) kalo ngomong, terus bisa menjaga perasaan gitu aja sih"

\section{Hubungan dengan keluarga}

Untuk masalah hubungan dengan keluarganya yang merupakan dua keluarga dengan latar belakang yang jauh berbeda, Andre mengungkapkan hal yang serupa namun sedikit berbeda dengan Alex, bahwa hubungannya dengan keluarga dari ayahnya yang merupakan Jawa, dirasa kurang berkomunikasi dan kurang dekat.

"ya kalo untuk keluarga dengan ayah itu kurang begitu dekat ya karena jauh, eh..kakaknya ayah saya itu di Jawa Barat, nah ada juga adiknya yang disini cuman jarang banget ketemu, mungkin kurang ada komunikasi ya kalau untuk keluarga dari papa"

Berbeda dengan Alex, Andre merasa lebih dekat dengan keluarga dari pihak ibunya yang merupakan keturunan Tionghoa,

"kalau di pihak ibu amat sangat dekat ya, hampir setiap kali ketemu karena ada keluarga yang di dekat rumah, terus yang jauh pun tetep mau nyambangin (berkunjung) ke rumah, nggak lose contact (kehilangan komunikasi) sama sekali cuma kalo keluarga di Jogja agak sedikit lose contact (kehilangan komunikasi) ya cuma kalo kitanya mau kesana langsung disediakan tempat untuk 
kami menginap jadi nggak ada problem (masalah) sama sekali untuk keluarga dari ibu."

Andre juga mengungkapkan bahwa keluarga dari pihak ibunya menghargai walaupun dirinya seorang muslim.

"meskipun mereka bukan Islam ya tetep aja mereka mau menghargai kami lah, orang-orang Islam.”

Hubungan dengan keluarga secara keseluruhan digambarkan Andre baik-baik saja dan tidak mengalami masalah berarti.

\section{Interaksi dengan lingkungan tempat tinggal}

Bertempat tinggal di perumahan Deltasari yang merupakan pemukiman yang multi etnis, membuat Andre banyak berinteraksi dengan banyak orang dari berbagai ras. Andre juga mengungkapkan dirinya banyak berinteraksi dengan yang lebih dewasa daripada dirinya.

"ya sama aja lah nggak ada perbedaan tetap ya namanya sama bapak-bapak kan pastinya mereka lebih dewasa daripada saya jadi ya lebih mengayomi gitu aja"

Namun Andre juga mengungkapkan bahwa interaksinya dengan sesama Tionghoa kurang begitu dekat.

\begin{abstract}
"sering, eh..mereka kebanyakan mereka memang sombong ya mungkin, karena kebanyakan eh..Cina itu, Cina itu ya kan sering dikiranya orang Cina itu pasti kaya, jadi mungkin ya karna itu mereka jadi sombong itu"
\end{abstract}

Walaupun hubungannya dengan sesama Tionghoa kurang begitu dekat namun secara umum Andre mengatakan bahwa dirinya tidak mengalami hambtan berarti terkait identitasnya. Hambatan yang dialaminya selama ini hanya masalah bahasa.

"mungkin bahasa ya, kan memang orang tua saya Cina ya, jadi ya bahasa yang diajarkan ke saya ya bahasa bakunya bahasa Indonesia jadi kalo untuk bahasa orang-orang Jawa asli ya kurang diajarkan ya, jadi kalo ngobrol sama orang-orang yang bahasanya meniko (itu) atau gimana gitu kurang paham jadi mesti tanya apa buk artinya gitu, jadi interaksinya kurang kalau sama orang Jawa, tapi kalau untuk sesama lancar-lancar aja tapi kalau untuk bahasa Jawa biasa gitu lancar-lancar aja."

Walaupun terkadang masih
terkendala bahasa, namun Andre mengungkapkan dan merasa bahwa saat ini keturunan Tionghoa mendapat perlakuan yang berbeda dari masyarakat pribumi. Dulunya keturunan Tionghoa sering mendapat perlakuan yang kurang berkenan bahkan pembantaian, namun sekarang keadaan tersebut berbalik dan dirinya merasa bahwa masyarakat pribumi, khususnya etnis Jawa saat ini lebih mengagungkan atau bahkan mengagumi Tionghoa, dikarenakan keunggulan fisik maupun materi.

"ya mungkin kalau sekarang lebih gimana ya, lebih suka dan mengagumi lah, karena jamannya sekarang kan orang Cina itu lebih mendominasi Indonesia ya, ya mungkin banyak artis-artis ya artis-artis Korea atau artis-artis Cina itu mungkin karena itu ya jadinya mungkin ada perubahan orang-orang Cina disini lebih dikagumi daripada orang Jawa aslinya ya."

Secara keseluruhan baik Andre maupun Alex mengungkapkan bahwa identitas mereka tidak mengahambat interaksi mereka sehari-hari, dan mereka tidak ingin membatasi pergaulan dikarenakan identitas mereka yang majemuk.

\section{PEMBAHASAN}

Sebagai seorang remaja, identitas sosial menjadi hal yang penting karena identitas sosial inilah yang nantinya akan menuntun mereka menjadi apa di masa depan, dan mempengaruhi cara pandang mereka serta secara langsung juga mempengaruhi interaksi mereka di masyarakat. Berdasarkan hasil 
wawancara yang dilakukan terhadap Alex dan Andre, terungkap bahwa permasalahan identitas ini menjadi penting saat mereka mulai memasuki masa remaja. Hal ini memang menjadi satu pokok bahasan penting terutama dalam ranah psikologi perkembangan maupun psikologi sosial, sebagaimana diungkapkan oleh Erik Erikson (dalam Santrock, 2002) dalam teorinya mengenai delapan tahap perkembangan psikososial, pada saat seorang individu memasuki fase remaja, mereka mengalami tahap perkembangan psikososial yang disebut identitas versus kebingungan identitas (identity versus identity confusion). Apabila individu berhasil melewati tahapan ini dengan baik, maka individu tersebut akan mampu memaknai dirinya sebagai seorang dengan identitas tertentu yang sesuai dengan dirinya. Namun hal yang berbeda terjadi apabila individu tersebut tidak mampu melewati tahapan tersebut dengan baik maka akan terjadi apa yang disebut kebingungan identitas. Keadaan ini akan mempengaruhi interaksinya dan juga pemaknaan dirinya.

Dalam kasus Alex dan Andre, masalah identitas ini menjadi tahapan yang berhasil mereka lalui dengan baik, sehingga di usia mereka yang menginjak masa remaja akhir mereka telah berhasil memaknai diri mereka dan menentukan identitas yang paling sesuai dengan diri mereka terkait status mereka yang merupakan keturunan campuran dan berhasil menyelesaikan tugas perkembangannya. Disini mereka lebih mengidentifikasikan diri mereka sebagai seorang Jawa daripada Tionghoa, dan lebih suka dianggap sebagai seorang Jawa daripada Tionghoa hal ini dikarenakan berbagai alasan, salah satunya karena lingkungan sekitar mereka yang didominasi oleh orang Jawa sehingga mereka merasa lebih nyaman diidentifikasikan sebagai orang Jawa. Namun mereka juga tetap mengakui bahwa mereka juga adalah seorang keturunan Tionghoa dan mengambil kebudayaan yang terbaik dari itu.

Sedangkan dipandang dari sudut pandang psikologi sosial, identitas menjadi salah satu konsep utama dalam interaksi sosial. Identitas sosial adalah hubungan antara individu dan lingkungannya. Identitas sosial lebih mengacu pada pertanyaan bagaimana seseorang di posisikan secara sosial (Stone, 1962 dalam Verkuyten, 2005). Dalam kasus Andre dan Alex, hal ini memiliki persamaan dan juga perbedaan. Persamaan diantara keduanya menyangkut masalah identitas agama. Dikarenakan merupakan keturunan Tionghoa, keduanya sama-sama mendapat “ cap" atau istilah psikologis sering disebut stereotip dari masyarakat sekitar, bahwa keturunan Tionghoa pasti seorang non muslim, sedangkan mereka merupakan muslim sejak lahir. Hal ini tentunya menjadi satu konflik tersendiri.

Selain itu masalah identitas agama ini juga mengakibatkan konflik tersendiri dalam keluarga mereka, terutama diakibatkan sebagian besar keluarga mereka yang memang non muslim. Dalam kasus Alex, dirinya sempat mengalami semacam kebingungan saat masih kecil. Hal ini dibuktikan dengan hasil wawancara dengan Alex bahwa dirinya sempat merasa bingung dengan konsep agama yang dianutnya, serta pernah mengikuti tata cara ibadah dari saudaranya yang menganut agama yang berbeda, dan dirinya tidak tahu bahwa hal tersebut salah. Hal ini sesuai dengan teori identitas sosial yang dikemukakan oleh Tajfel (dalam Lam, 2004) yang mengatakan bahwa identitas sosial adalah bagian dari self concept individu yang berasal dari pengetahuan mereka tentang keanggotaan mereka dalam kelompok sosial bersama dengan nilai dan signifikansi emosional yang terkait dengan kelompok tersebut (Tajfel, 1982, dalam Lam, 2004). Berdasarkan cerita Alex, dirinya merasa kurang mengetahui tentang konsep identitasnya, terutama identitas agamanya sehingga dirinya mengidentifikasikan identitas agamanya berdasarkan lingkungannya semasa kecil, tanpa mengetahui bahwa hal tersebut kurang sesuai dengan ajaran agama yang dianutnya Hal serupa diungkapkan oleh Andre, dikarenakan ibunya yang seorang keturunan Tionghoa dan juga kebetulan seorang muallaf, sehingga belum seberapa paham mengenai agama Islam. Andre mengakui bahwa dirinya sempat 
merasa bingung juga dengan konsep agama yang dianutnya dan mencoba memahaminya sendiri sehingga dirinya juga sempat merasa kebingungan karena orang tuanya tidak pernah mengajarkan ataupun memberi contoh. Hal-hal semacam ini memang secara sosial mempengaruhi seseorang dalam memaknai identitasnya, baik identitas etnis maupun identitas agamanya.

Di waktu yang bersamaan, batasan maupun informasi yang disediakan oleh identitas sosial ini sangatlah terbatas (Verkuyten, 2005). Seseorang tidak bisa dikatakan sepenuhnya berdasarkan karakteristik tertentu dan belum ada batasan yang jelas mengenai hal tersebut. Memiliki multiple identity seperti dalam kasus Alex dan Andre memiliki satu keuntungan tersendiri di satu sisi. Identitas sosial bukan merupakan sesuatu yang independen dan bisa berdiri sendiri, melainkan satu kesatuan yang memiliki hubungan satu sama lain (Verkuyten, 2005). Andre dan Alex bisa juga selain disebut keturunan Tionghoa, seorang muslim, seorang Jawa namun mereka juga bisa disebut sebagai warga Surabaya, bahkan sebagai penduduk Indonesia. Di sisi lain, untuk memenuhi tugas perkembangannya mereka diharuskan memilih identitasnya dan menetapkan mana yang paling sesuai dengan dirinya yaitu sebagai seorang Jawa atau Tionghoa.

Dalam kasus Andre misalnya, dalam berinteraksi dengan sesama keturunan Tionghoa namun non muslim dirinya merasa kurang nyaman, dikarenakan perbedaan status sosial. Identitas etnis mampu membuat sebagian orang membuat klasifikasi maupun tingkatan-tingkatan baik itu dalam hal gender, maupun status sosial. Dalam hal ini, Andre merasa bahwa Tionghoa yang non muslim dan memiliki status sosial lebih tinggi cenderung enggan berkumpul maupun berinteraksi dengan keturunan Tionghoa yang status sosialnya jauh lebih rendah. Mereka mengidentifikasikan kekayaan sebagai tolak ukur keberhasilan dan menganggap bahwa seseorang dengan status sosial lebih rendah adalah seseorang yang malas dan kurang berhasil dalam hidupnya. Hal ini disadari sepenuhnya oleh Andre sehingga sebagai keturunan campuran atau mixed ethnic people, Andre melakukan suatu hal yang disebut sebagai negosiasi identitas, . Negosiasi identitas ini sendiri dapat didefinisikan sebagai proses dimana penerima (perceivers) dan target memiliki persetujuan terkait identitas yang diasumsikan oleh target dalam interaksinya (Swann, 2005). Dalam hal ini yaitu dengan mengidentifikasikan dan berperilaku seperti kebiasaan orang Jawa sehingga dirinya akan teridentifikasi sebagai orang Jawa yang merupakan etnis mayoritas dan terhindar dari stigma-stigma tersebut. Negosiasi identitas ini juga terjadi pada Tionghoa muslim yang ada di Yogyakarta. Mereka akan mengidentifikasikan identitas ke Tionghoaan mereka sesuai dengan situasi yang ada dan perubahan yang terjadi di sekitar mereka (Maulana, 2010).

Hasil wawancara dengan partisipan pertama yaitu Alex, menunjukkan bahwa dirinya kurang dekat dengan keluarga ayahnya yang merupakan Tionghoa dan non muslim. Bahkan dirinya sering tidak diundang dalam acara-acara yang melibatkan keluarga besar. Di satu sisi dirinya merasa lebih dekat dengan keluarga dari pihak ibunya yang merupakan Jawa dan muslim. Hal ini menimbulkan konflik tersendiri dalam dirinya. Terlebih lagi stereotip di masyarakat bahwa Tionghoa pasti non muslim, dan konflik dalam keluarga ayahnya dikarenakan ayahnya memilih menjadi muslim membuat konflik psikologis dalam dirinya. Hal ini membuat tingkat well being Alex menjadi lebih rendah dikarenakan konflik antar identitas dalam dirinya terutama identitas yang penting, yaitu identitas etnis dan identitas agamanya. Sedangkan untuk kasus Andre, dirinya mengalami konflik psikologis pada saat anak-anak dimana banyak temannya yang mengejeknya dikarenakan dirinya keturunan Tionghoa. Namun saat menginjak remaja, hal itu sudah tidak terjadi. Selain itu juga terjadi perubahan di keluarganya khususnya keluarga dari ibunya yang merupakan Tionghoa, banyak yang mulai memeluk Islam dan menjadi muallaf, membuatnya merasa lebih percaya diri 
menjadi seorang keturunan Tionghoa muslim, dan meningkatkan pula kesejahteraan psikologisnya. Hal ini dikarenakan antar identitasnya bisa saling menfasilitasi satu sama lain.

\section{SIMPULAN}

Berdasarkan wawancara dan penelitian yang telah dilakukan, dapat diambil kesimpulan bahwa seseorang dengan multiple identity, khususnya dalam hal ini adalah keturunan Tionghoa Jawa yang memeluk agama Islam, memiliki strategi tertentu untuk mengidentifikasikan dirinya dan dalam memilih identitas yang paling sesuai dengan dirinya. Salah satu cara yang dilakukan adalah dengan negosiasi identitas, yakni dengan memilih satu dari identitas etnisnya untuk dijadikan identitasnya dalam interaksinya dengan mengikuti lingkungan mayoritas di sekitarnya.

Terkait negosiasi identitas ini, kedua partisipan disini memilih berperilaku dan mengikuti tradisi serta kultur masyarakat Jawa, yang mayoritas ada di lingkungannya serta lebih mengidentifikasikan diri mereka sebagai orang Jawa untuk menghindari perasaan terisolasi dan terkucilkan sebagai keturunan Tionghoa yang notabenenya adalah minoritas di Indonesia. Namun mereka juga tidak bisa sepenuhnya menjadi Jawa maupun sepenuhnya menjadi Tionghoa, dan untuk memenuhi tugas perkembangannya sebagai remaja, kedua partisipan memilih untuk mengambil kultur terbaik dari kedua identitas yang dimilikinya serta menggabungkannya untuk mencapai kesejahteraan psikologisnya.

\section{Daftar Pustaka}

Afif, Afthonul. (2009). "Strategi Mencapai Identitas Sosial Positif pada Orang Tionghoa Muslim di Yogyakarta". Yogyakarta. Tesis Fakultas Psikologi UGM.

Baron, A. Robert dan Donn Byrne. (2004). “ Psikologi Sosial Jilid 1 Edisi Kesepuluh". Jakarta : Erlangga.

Braun, V., \& Clarke, V. (2006). Using

Thematic Analysis in Psychology.

Qualitative Research in Psychology,

3, 77-101.

Bungin, Burhan. (2010). Analisis Data Penelitian Kualitatif. Jakarta : Rajagrafindo Persada.

Jendra, Randy S. (2012). Konsep Diri Muallaf Etnis Tionghoa. Bandung: Skripsi (tidak diterbitkan).

Lam, Joy. (2004). Religious Conversion and Reconstruction : The Case of Chinese Muslim Converts in Malaysia. The SouthEast Asia
Research Centre Working Paper. (Series no. 74).

Maulana, Rezza. (2010). Pergulatan Identitas Tionghoa Muslim: Sebuah Cerita dari Yogyakarta. Dipresentasikan dalam Annual Conference of Islamic Studies (ACIS) ke 10, Banjarmasin, 1 - 4 November 2010.

Perkasa, Adrian. (2012) " Orang-Orang Tionghoa dan Islam di Majapahit". Yogyakarta: Penerbit Ombak.

Santrock, John. W. (2002). Life Span Development. Jakarta : Erlangga.

Setiawan, Teguh. (2012). Cina Muslim dan Runtuhnya Republik Bisnis. Jakarta: Republika.

Setiono, G. Benny. (2005). Pasang Surut Hubungan Tionghoa Islam dalam Panggung Sejarah Indonesia. Dalam seminar Kontribusi Tionghoa dalam Penyebaran 
Islam di Indonesia, Jakarta, 19 Maret 2005.

Shelton, Nicole, Jennifer, A. R., \& Jaqcuie, D.R.( 2006). “ Threatened Identities and Interethnic Interactions". European Review of Social Psychology, 17, 321-358.

Siburian, Robert. (2004). " Etnis Cina di Indonesia dan Fakta Komunikasi Antar Budaya ”. Jurnal Ilmu
Komunikasi, hlm. 1-15.

Susetyo, Budi. (2010). “ Stereotip dan Relasi Antarkelompok". Yogyakarta : Graha Ilmu

Swann Jr, William. (2005). The Self and Identity Negotiation. Journal of Interaction Studies. 6 (1), 69 : 83.

Verkuyten, Maykel. (2005). "The Social Psychology of Ethnic Identity." New York : Psychology Press. 